\title{
PELAKSANAAN CORPORATE SOCIAL RESPONSIBILITY OLEH PERUSAHAAN TIDAK BERBADAN HUKUM
}

\author{
Dora Yulia Agustina \\ Program Kenotariatan Fakultas Hukum Universitas Bengkulu \\ dora.yulia32@gmail.com
}

\begin{abstract}
This study aims to find out and examine the form of CSR implementation carried out by Buana Trade Business and the suitability of its implementation with the Caroll CSR Doctrine. Corporate Social Responsibility (CSR) is the company's obligation to develop the company and contribute to the welfare of society and environmental sustainability in order to create harmonious relations. There are still less than 50\% of companies that have implemented CSR because they think CSR is not an obligation. The arrangement of procedures for implementing CSR for companies that are not incorporated has not been further regulated in legislation. Business Trade Lang-Lang Buana is one of the fisheries companies that have implemented CSR. The problem is whether the form and suitability of CSR has been carried out in accordance with the existing CSR doctrine. This legal research method uses an empirical legal approach. The results of the study show that: (1) Lang-lang Buana's business has implemented corporate social responsibility in the form of economic, social and environmental aspects (2) The corporate social responsibility carried out is in accordance with CSR Caroll doctrine where the three forms of corporate social responsibility has covered four elements of Caroll's CSR, which are economic, legal, ethical and philanthropic.
\end{abstract}

Keywords : Company; Corporate social responsibility; Legal entity

\begin{abstract}
Abstrak
Penelitian ini bertujuan untuk mengetahui dan mengkaji bentuk pelaksanaan CSR yang dilakukan oleh Usaha Dagang Lang-lang Buana dan kesesuaian pelaksanaannya dengan Doktrin CSR Caroll. Tanggung Jawab Sosial Perusahaan/Corporate Social Responsibility (CSR) adalah kewajiban perusahaan untuk mengembangkan perusahaan dan turut berkontribusi dalam mensejahterahkan masyarakat serta kelestarian lingkungan agar terciptanya hubungan yang harmonis. Masih kurang dari $50 \%$ perusahaan yang telah melaksanakan CSR karena menganggap CSR bukan sebagai kewajiban. Pengaturan tata cara pelaksanaan CSR untuk perusahaan yang tidak berbadan hukum belum diatur lebih lanjut dalam peraturan perundang-undangan. Usaha Dagang Lang-Lang Buana merupakan salah satu perusahaan perikanan yang telah melaksanakan CSR,. Persoalannya apakah bentuk dan kesesuaian CSR yang telah dilakukan sesuai dengan doktrin CSR yang ada. Metode penelitian hukum ini menggunakan pendekatan hukum empiris. Hasil penelitian menunjukkan bahwa: (1) Usaha Dagang Lang-lang Buana telah melaksanakan tanggung jawab sosial perusahaan dalam bentuk ekonomi, sosial dan lingkungan (2) Tanggung jawab sosial perusahaan yang dilakukan telah sesuai dengan dokrin CSR Caroll dimana ketiga bentuk tanggung jawab sosial perusahaan ini telah mencakup empat unsur CSR Caroll yakni ekonomi, hukum, etika dan philanthropic.
\end{abstract}

Kata Kunci : Perusahaan; Tanggung Jawab Sosial Perusahaan; Badan Hukum

\section{PENDAHULUAN}

Kesejahteraan masyarakat Indonesia tidak semata-mata merupakan tanggung jawab salah satu pihak saja, akan tetapi tanggung jawab semua yang

Dora Yulia Agustina, Pelaksanaan Corporate Social Responsibility Oleh perusahaan tidak berbadan hukum.... 
berkepentingan (stakeholders) seperti perusahaan yang ikut menikmati kekayaan negara Republik Indonesia. Aulia muthia menyebutkan perusahaan merupakan setiap bentuk usaha yang melakukan kegiatan secara tetap dan terus menerus dengan tujuan memperoleh keuntungan atau laba, baik yang diselenggarakan oleh orang perorangan maupun badan usaha yang berbentuk badan hukum atau bukan badan hukum. ${ }^{1}$

Bentuk tanggung jawab perusahaan dikenal sebagai tanggung jawab sosial perusahaan/Corporate Social Responsibility (CSR). Corporate Social Responsibility (CSR) sebagai salah satu pilar Good Corporate Governance (GCG), yang pelaksanaannya merupakan hal yang penting yang harus dilakukan oleh perusahaan. CSR merupakan bentuk pertanggungjawaban sosial perusahaan kepada stakeholders sudah menjadi tuntutan jaman ditengah dunia bisnis yang sudah berubah. ${ }^{2}$

Kewajiban melakukan tanggung jawab sosial perusahaan telah tertera dalam Undang-Undang Nomor 40 tahun 2007 tentang Perseroan Terbatas dan Undang-Undang Nomor 25 tahun 2007 tentang Penanaman Modal. UndangUndang Nomor 40 tahun 2007 tentang Perseroan Terbatas menyebut tanggung jawab sosial perusahaan dengan sebutan tanggung jawab sosial dan lingkungan.

Tanggung jawab sosial dan lingkungan dimuat dalam Pasal 1 butir 3 Undang-Undang Nomor 40 tahun 2007 tentang Perseroan Terbatas, yang isinya : Tanggung jawab sosial dan lingkungan adalah komitmen Perseroan untuk berperan serta dalam pembangunan ekonomi berkelanjutan guna meningkatkan kualitas kehidupan dan lingkungan yang bermanfaat, baik bagi Perseroan sendiri, komunitas setempat, maupun masyarakat pada umumnya.

Penjelasan Pasal 15 huruf b Undang-Undang Nomor 25 tahun 2007 Tentang Penanaman Modal menyebutkan bahwa yang dimaksud dengan tanggung jawab sosial perusahaan adalah: Tanggung jawab yang melekat pada setiap perusahaan penanaman modal untuk tetap menciptakan hubungan yang serasi, seimbang, dan sesuai dengan lingkungan, nilai, norma, dan budaya masyarakat setempat.

Definisi corporate social responsibility masih belum ada satupun yang disetujui secara global, karena definisi CSR dan komponen CSR dapat berbedabeda di negara atau daerah yang lain, namun umumnya CSR berbicara hubungan antara perusahaan dan stakeholders yang di dalamnya terdapat nilai-nilai pemenuhan ketentuan hukum, maupun penghargaan terhadap masyarakat dan lingkungan, serta komitmen perusahaan untuk berkontribusi dalam pembangunan berkelanjutan. ${ }^{3}$

${ }_{1}$ Aulia Muthiah, Aspek Hukum Dagang dan Pelaksanaannya Di Indonesia, Yogyakarta: PT. Pustaka Baru, 2016, hlm. 17.

2 Nur Sulistyo B Ambarini, "Corporate Social Responsibility (CSR) Sebagai Instrumen Hukum Ekonomi Di Era Globalisasi", Jurnal Dinamika Hukum, Jilid 10 Terbitan 3, 15 Oktober 2010, hlm. 7, diunduh dari http://www.dinamikahukum.fh.unsoed.ac.id/index.php/JDH/article/viewFile/10 $\underline{1 / 51}$ tanggal 25 Maret 2017.

3 Farida Hasyim, Hukum Dagang, Jakarta: Sinar Grafika, 2009, hlm. 146.

Dora Yulia Agustina, Pelaksanaan Corporate Social Responsibility Oleh perusahaan tidak berbadan hukum.... 
Secara lengkap kewajiban pelaksanaan tanggung jawab sosial dan lingkungan dijabarkan dalam Pasal 74 Undang-Undang Nomor 40 tahun 2007 tentang Perseroan Terbatas sebagai berikut :

(1) Perseroan yang menjalankan kegiatan usahanya di bidang dan/atau berkaitan dengan sumber daya alam wajib melaksanakan Tanggung Jawab Sosial dan Lingkungan.

(2) Tanggung Jawab Sosial dan Lingkungan yang dimaksud pada ayat (1) merupakan kewajiban Perseroan yang dianggarkan dan diperhitungkan sebagai biaya Perseroan yang pelaksanaanya dilakukan dengan memperhatikan kepatutan dan kewajaran.

(3) Perseroan yang tidak melaksanakan kewajiban sebagaimana dimaksud pada ayat (1) dikenai sanksi sesuai dengan ketentuan peraturan perundangundangan.

(4) Ketentuan lebih lanjut mengenai Tanggung Jawab Sosial dan Lingkungan diatur dengan Peraturan Pemerintah.

Bila dibaca dengan cermat ketentuan di atas tampak bahwa perusahaan bukan hanya sekedar berkomitmen dalam melaksanakan Tanggung Jawab Sosial dan Lingkungan, akan tetapi sudah menjadi kewajiban perseroan untuk melaksanakan kewajiban Tanggung Jawab Sosial dan Lingkungan (TJSL). ${ }^{4}$

Kewajiban pelaksanaan tanggung jawab sosial dan lingkungan juga diatur dalam Pasal 15 Undang-Undang Nomor 25 tahun 2007 tentang Penanaman Modal setiap penanam modal berkewajiban :
a. Menerapkan prinsip tata kelola perusahaan yang baik;
b. Melaksanakan tanggung jawab sosial perusahaan;
c. Membuat laporan tentang kegiatan penanaman modal dan menyampaikannya kepada Badan Koordinasi Penanam Modal;
d. Menghormati tradisi budaya masyarakat sekitar lokasi kegiatan usaha penanam modal; dan
e. Mematuhi semua ketentuan peraturan perundang-undangan.

Dalam Undang-Undang Nomor 25 Tahun 2007 Tentang Penanaman Modal tidak ada pembatas terhadap bentuk perusahaan dan bidang usahanya, sedangkan dalam Undang-Undang Nomor 40 Tahun 2007 Tentang Perseroan Terbatas hanya diperuntukkan bagi bentuk perusahaan perseroan terbatas khususnya yang bergerak di bidang sumber daya alam.

Tata cara pelaksanaan tanggung jawab sosial perusahaan untuk perusahaan berbentuk perseroan terbatas dan perusahaan berbadan hukum lainnya sudah di atur dalam peraturan perundang-undangan, akan tetapi untuk perusahaan yang tidak berbadan hukum belum ada peraturan yang mengaturnya. Perusahaan yang tidak berbadan hukum dapat beracuan pada sumber hukum lainnya untuk melaksanakan tanggung jawab sosial perusahaan, salah satunya doktrin.

4 Sentosa Sembiring, Hukum Perseroan Tentang Perseroan Terbatas, Bandung: CV. Nuansa Aulia, 2007, hlm 192.

Dora Yulia Agustina, Pelaksanaan Corporate Social Responsibility Oleh perusahaan tidak berbadan hukum.... 
Doktrin termasuk salah satu sumber hukum, yaitu sumber hukum formil. Sehingga doktrin CSR ini dapat dijadikan sebagai panduan dalam pelaksanaan CSR. Archie B. Carrol (Professor at the University of Georgia), menyatakan bahwa empat jenis tanggung jawab sosial merupakan keseluruhan CSR, yaitu tanggung jawab ekonomi (membuat keuntungan), tanggung jawab hukum (mematuhi hukum), tanggung jawab etika (etis), dan tanggung jawab philanthropic (menjadi warga korporasi yang baik). 5

Caroll dalam Totok memberikan definisi CSR lebih lanjut dalam empat bagian dari CSR : 6

In my view, CSR involves the conduct pf a business so that it is economically profitable, law abiding, ethical and socially supportive. To be socially responsible then means that profitability and obedience to the law are foremost conditions to discussing the firm's ethics and the extent to which it supports the society in which it exists with contributions of money, time and talent. Thus, CSR is composed of four parts : economic, legal, ethical and voluntary or philanthropic. (Dalam pandangan saya, CSR meliputi pelaksanaan bisnis sehingga ekonomi menguntungkan, taat hukum, etika dan sosial mendukung. Untuk bertanggungjawab secara sosial, maka berarti bahwa profitabilitas dan ketaatan kepada hukum adalah kondisi utama untuk membahas etika perusahaan dan sejauh mana ia mendukung masyarakat di mana ia ada dengan kontribusi uang, waktu, dan bakat. Dengan demikian, CSR terdiri dari empat bagian : ekonomi, hukum, etika dan sukarela atau filantropi. (Caroll, 1983)

Beberapa alasan mengapa CSR perlu dilaksanakan ${ }^{7}:(1)$ Merupakan hal etis yang dilakukan; (2) Meningkatkan citra perusahaan; (3) Hal ini diperlukan dalam rangka untuk menghindari peraturan yang berlebihan; (4) Jenis kegiatan tanggung jawab sosial dapat juga menguntungkan; (5) Lingkungan sosial yang lebih baik akan bermanfaat bagi perusahaan; (6) Dapat menarik minat para investor; (7) Dapat meningkatkan motivasi karyawan; (8) Dapat membantu untuk memperbaiki masalah sosial yang disebabkan oleh bisnis.

Menurut Gurvy Kavei, pakar manajemen dari Universitas Manchester, Inggris, menegaskan bahwa setiap perusahaan yang mengimplementasikan CSR dalam aktivitas usahanya akan mendapatkan 5 (lima) manfaat utama sebagai berikut8:

1) Meningkatkan profitabilitas dan kinerja finansial yang lebih kokoh, misalnya lewat efisiensi lingkungan;

2) Meningkatkan akuntabilitas, assessment dan komunitas investasi;

3) Mendorong komitmen karyawan, karena mereka diperhatikan dan dihargai;

4) Menurunkan kerentanan gejolak dengan komunitas; dan

5) Mempertinggi reputasi dan corporate branding.

5 Totok Mardikanto, CSR (Corporate Social Responsibility) (Tanggung Jawab Sosial Korporasi), Bandung: ALFABETA, 2014, hlm. 180.

6 Ibid, hlm. 118.

7 Ibid, hlm. 129.

8 Isa Wahyudi dan Busyra Azheri, Corporate Social Responsibility : Prinsip, Pengaturan dan Implementasi, Malang: In-Trans Publishing, 2008, hlm. 124-125.

Dora Yulia Agustina, Pelaksanaan Corporate Social Responsibility Oleh perusahaan tidak berbadan hukum.... 
Kewajiban Pelaksanaan tanggung jawab sosial perusahaan dan pentingnya tanggung jawab sosial perusahaan dilaksanakan tidak membuat perusahaan taat mematuhi perintah undang-undang ini. Antara News (2007) lewat artikel "Kurang dari 50 Persen Perusahaan Laksanakan CSR" menyebutkan bahwa: Pelaksanaan tanggung jawab sosial perusahaan di Indonesia sejauh ini masih sangat kurang, karena kurang dari 50\% perusahaan di Indonesia yang memperhatikan dan melakukan kegiatan tanggung jawab sosial perusahaan terlebih khususnya dalam kegiatan di bidang lingkungan. ${ }^{9}$

Banyak perusahaan yang belum melakukan tanggung jawab sosial perusahaan dan masih banyak perusahaan yang menganggap kegiatan tanggung jawab sosial perusahaan hanya merupakan kegiatan sukarela (voluntary), sedangkan kegiatan tanggung jawab sosial perusahaan lebih merupakan suatu komitmen bersama yang berkelanjutan dari perusahaan untuk bersama-sama bertanggung jawab terhadap masalah-masalah sosial.

Terdapat sembilan (9) perusahaan perikanan yang terdapat di provinsi Bengkulu, salah satunya yakni Usaha Dagang Lang-lang Buana. ${ }^{10}$ Usaha Dagang Lang-lang Buana berdiri pada tahun 1990 dan beralamat di jalan Kampung Bahari, Kelurahan Sumber Jaya, Kecamatan Kampung Melayu, Kota Bengkulu. Perusahaan ini bergerak dibidang perikanan ikan tangkap. ${ }^{11}$

Ditengah banyaknya perusahaan yang tidak melaksanakan tanggung jawab sosial perusahaan, Usaha Dagang Lang-lang Buana tetap melaksanakan tanggung jawab sosial perusahaan walaupun untuk perusahaan yang tidak berbadan hukum belum ada peraturan perundang-undangan yang mengatur tata cara pelaksanaan tanggung jawab sosial perusahaan.

Teori yang digunakan yakni Teori triple bottom line dikemukakan oleh Jhon Elkington. Elkington memberi pandangan bahwa jika sebuah perusahaan ingin mempertahankan kelangsungan hidupnya, maka perusahaan tersebut harus memperhatikan 3P. Selain mengejar keuntungan (profit), perusahaan juga harus memperhatikan dan terlibat pada pemenuhan kesejahteraan masyarakat (people) dan turut berkontribusi aktif dalam menjaga kelestarian lingkungan (planet). ${ }^{12}$

Dalam gagasan tersebut perusahaan tidak lagi dihadapkan pada tanggung jawab yang berpijak pada singel bottom line, yaitu aspek ekonomi yang direfleksikan dalam kondisi keuangan saja, namun juga harus memperhatikan aspek sosial dan lingkungannya. ${ }^{13}$

Penelitian ini untuk mengetahui bentuk tanggung jawab sosial perusahaan yang telah dilakukan Usaha Dagang Lang-Lang Buana dan bentuk tanggung jawab

9 Ruslan Burhani, "Kurang dari 50 Persen Perusahaan Laksanakan CSR", diunduh dari http://m.antaranews.com/berita/68802/kurang-dari-50-persenperusahaan-laksanakan-csr , tanggal 16 Oktober 2016.

10 Dinas Kelautan dan Perikanan Provinsi Bengkulu, Bengkulu, tanggal 5 Maret 2017.

11 Usaha Dagang Lang-lang Buana, Bengkulu, tanggal 10 November 2016.

12 Gunawan Widjaja dan Yeremia Ardi Pratama, Risiko Hukum dan Bisnis Perusahaan Tanpa CSR, Jakarta: Forum Sahabat, 2008, hlm.33.

13 Ibid, hlm.33.

Dora Yulia Agustina, Pelaksanaan Corporate Social Responsibility Oleh perusahaan tidak berbadan hukum.... 
yang dilakukan telah sesuai atau tidak dengan doktrin CSR Caroll, karena tidak adanya peraturan yang mengatur tata cara pelaksanaan CSR untuk badan usaha tidak berbadan hukum. Pelaksanaan CSR perusahaan yang tidak berbadan hukum ini belum pernah dibahas karena minimnya perusahaan yang melakukan CSR terlebih lagi perusahaan yang belum berbadan hukum dimana belum adanya ketentuan tata cara pelaksanaannya.

\section{METODE PENELITIAN}

Penelitian ini merupakan penelitian hukum yang dilakukan dengan menggunakan metode pendekatan sosio legal research. Penelitian ini akan memberikan suatu gambaran tentang penerapan tanggung jawab sosial perusahaan (corporate social responsibility) yang dilakukan oleh Usaha Dagang Lang-lang Buana di Kota Bengkulu. Dengn pendekatan sosio legal research, penelitian ini berupaya menemukan hal-hal berkaitan proses terjadinya dan mengenai proses bekerjanya hukum di dalam masyarakat.

Pengumpulan data primer yang dilakukan peneliti di lapangan diperoleh dari hasil wawancara. Data sekunder adalah data yang memberikan penjelasan mengenai data primer. Dalam penelitian ini data sekunder berasal dari sumber pustaka berupa peraturan perundang-undangan, buku, jurnal, dan artikel baik media online maupun offline terkait dengan Tanggung Jawab Sosial Perusahaan dengan menggunakan teknik studi kepustakaan.

Seluruh data yang terkumpul melalui penelitian kepustakaan dan lapangan diolah dengan editing data. Editing data adalah memeriksa atau meneliti data yang telah diperoleh untuk menjamin apakah sudah dapat dipertanggungjawabkan sesuai dengan kenyataan. ${ }^{14}$ Analisis data dalam penelitian ini dilakukan secara kualitatif. Analisis kualitatif artinya menguraikan data secara bermutu dalam bentuk kalimat yang teratur, runtun, logis, tidak tumpang tindih, dan efektif, sehingga memudahkan pemahaman dan interprestasi data. ${ }^{15}$

\section{HASIL DAN PEMBAHASAN}

\section{Bentuk Tanggung Jawab Sosial Perusahaan (Corporate Social Responsibility) yang Dilakukan Oleh Usaha Dagang Lang-lang Buana Di Kota Bengkulu}

Perusahaan perikanan Usaha Dagang Lang-lang Buana telah melakukan beberapa kegiatan terkait dengan pelaksanaan tanggung jawab sosial perusahaan. Kegiatan yang dilakukan perusahaan mencakup tiga bentuk yakni ekonomi, sosial dan lingkungan sesuai dengan teori tripple bottom line.

Motivasi utama dari setiap kegiatan usaha yakni mencari keuntungan (profit), oleh karena itu berbagai upaya akan dilakukan oleh setiap pengelola perusahan untuk mendapatkan keuntungan. Sustainability ekonomi perusahaan merupakan dasar bagi perusahaan dalam menjaga sustainability sosial dan

14 Roni Hanitiyo Sumitro, Metodologi Penelitian Hukum dan Jurimetri, Jakarta: Ghalia Indonesia, 1990, hlm. 64.

15 Abdulkadir Muhammad, Hukum dan Penelitian Hukum, Bandung: PT. Citra Aditya Bakti., 2004, hlm. 172.

Dora Yulia Agustina, Pelaksanaan Corporate Social Responsibility Oleh perusahaan tidak berbadan hukum.... 
lingkungan. Perusahaan akan dapat menjaga sustainability sosial dan lingkungan jika perusahaan tersebut mendapatkan keuntungan. ${ }^{16}$

CSR di bidang ekonomi dapat dirumuskan sebagai kewajiban untuk berperan serta dalam meningkatkan taraf hidup masyarakat. Usaha Dagang Langlang Buana dalam meningkatkan taraf hidup masyarakat terutama masyarakat pesisir dengan melakukan pemberian modal dalam bentuk alat tangkap ikan. Pemberian alat tangkap ini dilakukan pada tahun 2016. Alat tangkap yang diberikan berupa lancang dan jaring, masing-masing mendapatkan satu lancang dan satu jaring. Nelayan yang mendapatkan alat tangkap ini yakni nelayan di kelurahan Pasar Bengkulu. ${ }^{17}$

Bidang sosial ditunjukkan dengan menjadi warga korporasi yang baik yakni dengan menjalin hubungan dengan masyarakat salah satunya dengan melaksanakan tanggung jawab sosial terhadap masyarakat. Usaha Dagang Langlang Buana telah melakukan beberapa kegiatan diantaranya :

a. Perbaikan Masjid

Perbaikan masjid yang dilakukan Usaha Dagang Lang-lang Buana dianggarkan dari dana perusahaan yaitu $2,5 \%$ dari hasil kapal. Setiap tahun jumlahnya tidak pasti berapa masjid yang mendapatkan bantuan dana, tergantung dari proposal yang masuk ke perusahaan. Bantuan dana pembangunan maupun perbaikan masjid rata-rata setiap masjid yang mengajukan proposal mendapatkan Rp 1.000.000,- (Satu Juta Rupiah) dan sisa dana yang dianggarkan diberikan kepada masjid yang menjadi prioritas. ${ }^{18}$

Salah satu masjid di Kota Bengkulu yang menjadi prioritas yakni Masjid Mujahidin yang terletak di Kelurahan Pasar Bengkulu. Kamaludin yakni pengurus masjid mengatakan perbaikan dilakukan pada tahun 2000 sampai dengan sekarang. Semua kebutuhan masjid akan dipenuhi oleh pihak perusahaan. 19

Masjid yang juga menerima bantuan yakni Masjid Mardhatillah yang juga terletak di Kelurahan Pasar Bengkulu. Saharudin yakni pengurus masjid mengatakan bahwa penerimaan bantuan dimulai sejak terjadinya gempa bumi di Bengkulu yakni pada tahun 2000. Kondisi masjid yang rusak akibat gempa membuat Perusahaan Lang-lang Buana membantu perbaikan masjid hingga sekarang. Setiap tahunnya rata-rata Masjid Mardhatillah mendapatkan bantuan dana sebesar RP 5.000.000,- (Lima Juta Rupiah). ${ }^{20}$

b. Haji dan Umroh Gratis

Setiap tahunnya rata-rata $15-20$ orang mendapat umroh gratis dan 4-5 orang untuk berangkat haji gratis. Penerima berangkat umroh dan haji gratis ini terdiri dari warga masyarakat Kota Bengkulu, karyawan Usaha Dagang Lang-

16 Gunawan Widjaja, dan Yeremia Ardi Pratama, Op.Cit., hlm. 45.

17 Mulyadi (nelayan), Hasil wawancara, Bengkulu tanggal 28 Maret 2017.

18 Sisi Prisilia dan Epi sulastri, Op.Cit.

19 Kamaludin (Pengurus Masjid Mujahidi), Hasil wawancara, Bengkulu, tanggal 27 Februari 2017.

20 Saharudin (Pengurus Masjid Mardhatillah), Hasil wawancara, Bengkulu, tanggal 27 Februari 2017.

Dora Yulia Agustina, Pelaksanaan Corporate Social Responsibility Oleh perusahaan tidak berbadan hukum.... 
lang Buana, pengurus masjid serta jemaat masjid. Penerima haji gratis dimulai sejak tahun 2004 sampai dengan 2010 dilaksanakan dua tahun sekali. Umroh gratis sampai sekarang masih dijalankan. Haji gratis tidak jalankan lagi karena untuk mendaftar haji sampai dengan keberangkatan memerlukan waktu tunggu yang lama sehingga hanya umroh yang masih berjalan.

Saharudin salah satu penerima berangkat haji gratis pada tahun 2008 mengatakan sangat senang mendapatkan biaya untuk berangkat haji. Semua keperluan dari mendaftar hingga pulang haji telah diurus oleh perusahaan, untuk keluarga yang ditinggalkan juga diberikan dana untuk keperluan seharihari yakni senilai Rp 2.000.000,- (Dua Juta Rupiah). ${ }^{21}$

Salah satu karyawan yang juga mendapatkan umroh gratis yakni badarudin, beliau mendapatkan berangkat umroh gratis pada tahun 2015. Pada saat pengurusan pendaftaran hingga pulang dari umroh semua telah diurus oleh pemilik perusahaan dan juga mendapatkan uang saku selama di tanah suci. ${ }^{22}$ Yulines salah satu warga kelurahan Pasar Bengkulu juga mendapatkan umroh gratis ini. Yulines mendapatkan berangkat umroh gratis ini pada tahun 2014. Sama seperti penjelasan saharudin dan badarudin bahwa semua telah diurus oleh perusahaan dari proses pendaftran hingga kembali ketanah air. ${ }^{23}$

c. Pembagian Sembako

Pembagian sembako ini dilakukan setiap tahun pada awal Bulan Ramadhan. Penerima sembako yakni panti asuhan dan masyarakat yang kurang mampu yang berada di Provinsi Bengkulu. Setiap tahunnya yang mendapatkan sembako berjumlah kurang lebih 700 orang. Sembako yang diberikan kepada masyarakat terdiri dari beras, ikan, gula dan uang yang berjumlah Rp. 50.000,- (Lima Puluh Ribu Rupiah). ${ }^{24}$

Panti asuhan Bumi Rafflesia yang diketuai oleh Azizah beralamat di Jalan Kesehatan I Nomor 32 RT 4 RW 2 Kelurahan Anggut Atas, Kecamatan Ratu Samban, Kota Bengkulu merupakan salah satu penerima sembako. Panti asuhan ini dalam pembagian sembako mendapatkan ikan satu peti dan beras lima karung. ${ }^{25}$

Amaria salah satu penerima sembako mengatakan setiap tahunnya dia selalu mendapatkan undangan untuk menerima sembako yang diadakan di kediaman pemilik Usaha Dagang Lang-lang Buana di Jalan Nuzirwan Zainul, Kampung Bali, Kota Bengkulu. Pembagian sembako diisi dengan ceramah terlebih dahulu,

21 Ibid.

22 Badarudin Karyawan Usaha Dagang Lang-Lang Buana, Hasil Wawancara, Bengkulu, tanggal 26 Februari 2017.

23 Yulines (Warga Pasar Bengkulu), Hasil wawancara, Bengkulu, tanggal 27 Februari 2017.

24 Sisi Prisilia dan Epi sulastri, Op.Cit.

25 Nur Baiti (Petugas Pencari Dana Panti Asuhan Bumi Rafflesia), Hasil wawancara, Bengkulu, tanggal 7 Maret 2017.

Dora Yulia Agustina, Pelaksanaan Corporate Social Responsibility Oleh perusahaan tidak berbadan hukum.... 
baru kemudian dilaksanakan pembagian sembako dengan menunjukkan undangan yang telah diberikan sebelumnya. ${ }^{26}$

Yara salah satu penerima sembako mengatakan bahwa dia merasa senang dengan adanya pembagian sembako ini dan merasa terbantu, apalagi pembagian sembako diadakan pada Bulan Ramadhan sehingga dapat mencukupi kebutuhan untuk menjalankan ibadah Ramadhan. ${ }^{27}$

d. Makan dan Doa Bersama

Makan dan doa bersama ini dilakukan satu tahun sekali, dimana yang menjadi undangannya yaitu anak yatim, jompo dan fakir miskin. Sama halnya dengan pembagian sembako, makan dan doa bersama ini dihadiri kurang lebih 700 orang. Kegiatan makan dan doa bersama ini diisi dengan ceramah dan doa bersama serta makan-makan, setelah kegiatan selesai setiap undangan mendapatkan uang seniali Rp 100.000,- (Seratus Ribu Rupiah). Rani salah satu penerima undangan menceritakan bahwa setiap tahunnya ia mendapatkan undangan untuk makan dan doa bersama. Kegiatan doa bersama ini dilakukan dikediaman pemilik perusahaan. ${ }^{28}$

e. Pembentukan Klub Basket

Usaha Dagang Lang-lang Buana menyediakan wadah untuk anak muda Bengkulu yang gemar bermain basket dengan menyediakan fasilitas tempat dan pelatih untuk mengasah kemampuan bermain basket. Klub basket Lang-lang Buana ini terdiri dari putra dan putri, dimana jumlah pemain basket putra 30 orang dan 20 orang putri. ${ }^{29}$

Resty Ramadayanti salah satu anggota klub basket putri mengatakan bahwa tidak ada seleksi atau syarat untuk masuk dalam klub basket Lang-lang Buana, klub terbuka untuk umum setiap yang ingin masuk dan berlatih dapat langsung bergabung dan latihan sesuai jam latihan yang telah ditentukan yakni jam 20.00 WIB hari senin dan kamis setiap minggunya. ${ }^{30}$

Erin larini salah satu anggota klub juga mengatakan bahwa tidak ada pungutan untuk bergabung dalam klub basket. Semua kebutuhan telah disediakan dan dipenuhi oleh pemilik Usaha Dagang Lang-lang Buana. Bila ada pertandingan maka dari seluruh anggota klub akan diseleksi untuk menentukan siapa yang akan bertanding mewakili klub. Dalam pertandingan apabila klub Lang-lang Buana mendapatkan juara maka tim akan mendapatkan reward jalan-jalan dan makan-makan dari pemilik perusahaan. ${ }^{31}$

26 Amaria (Warga Kampung Kelawi), Hasil wawancara, Bengkulu, tanggal 11 Maret 2017. Maret 2017.

27 Yara (Warga Kampung Kelawi), Hasil Wawancara, Bengkulu, tanggal 11 Maret 2017.

28 Rani (Warga Kampung Kelawi), Hasil wawancara, Bengkulu, tanggal 11

29 Erin Larini (Angota Klub Basket LLB), Hasil Wawancara, Bengkulu, tanggal 4 Maret 2017.

30 Resty Ramadayanti (Angota Klub Basket LLB), Hasil Wawancara, Bengkulu, tanggal 4 Maret 2017.

${ }^{31}$ Erin Larini, Op.Cit.

Dora Yulia Agustina, Pelaksanaan Corporate Social Responsibility Oleh perusahaan tidak berbadan hukum.... 
Bidang lingkungan hidup berkaitan dengan kewajiban memelihara kelestarian lingkungan yang termuat dalam Pasal 67 Undang-Undang Nomor 32 tahun 2009 tentang Perlindungan Dan Pengolahan Lingkungan Hidup sebagai berikut : Setiap orang berkewajiban memelihara kelestarian fungsi lingkungan hidup serta mengendalikan pencemaran dan/atau kerusakan lingkungan hidup. Kewajiban ini juga termuat dalam Pasal 68 huruf b Undang-Undang Nomor 32 tahun 2009 tentang Perlindungan Dan Pengolahan Lingkungan Hidup, bahwa setiap orang yang melakukan usaha dan/atau kegiatan berkewajiban menjaga keberlanjutan fungsi lingkungan hidup.

Pada saat penelitian ini dilakukan, belum ada kegiatan khusus dari Usaha Dagang Lang-lang Buana dalam menjaga lingkungan pantai dimana tempat perusahaan menjalankan kegiatan usahanya. Hal yang dilakukan perusahaan adalah dengan meminimalisir dampak yang ditimbulkan dari kegiatan penangkapan ikan yakni dengan menggunakan alat tangkap yang sesuai dengan prosedur agar tidak mengganggu perkembangbiakan ikan secara alami. Alat tangkap yang digunakan oleh Usaha Dagang Lang-lang Buana yakni pukat cincin (purse seine). ${ }^{32}$

Kegiatan dibidang lingkungan yang pernah dilakukan yakni melakukan pogging nyamuk secara gratis di Kampung bali pada tahun 2016 dan kebersihan pantai di Pulau Baai dan Pasar Bengkulu pada tahun 2015. Kebersihan lingkungan pantai dilakukan dengan menggerakkan masyarakat di pinggir pantai terutama nelayan sekitar dengan memfasilitasi kebutuhan makan dan minum. ${ }^{33}$ Masyarakat yang rumahnya mendapatkan pogging gratis merasa senang karena dapat meminimalisir nyamuk berkembangbiak disekitar rumah dan terhindar dari penyakit yang dibawa oleh nyamuk. Pogging gratis ini baru pertamakali dilakukan oleh Usaha Dagang Lang-lang Buana. ${ }^{34}$

\section{Kesesuaian Pelaksanaan Tanggung Jawab Sosial Perusahaan Usaha Dagang Lang-lang Buana dengan Doktrin CSR Caroll}

Usaha Dagang Lang-lang Buana telah bertahan puluhan tahun dalam melakukan kegiatan usahanya, perusahaan ini dapat bertahan dengan terus mempertahankan kualitas kesegaran ikan hasil tangkapan dengan proses penyimpanan yang baik. Kualitas ikan yang baik membuat rekan bisnis senang dalam bekerjasama.Usaha Dagang Lang-lang Buana juga terus berupaya meningkatkan teknologi yang dimiliki dalam menangkap ikan agar mengetahui dimana posisi ikan yang banyak agar jumlah tangkapan yang didapatpun juga banyak. Salah satu upaya meminimalisir pengeluaran perusahaan dengan membuat pabrik es sendiri yang digunakan untuk mencukupi kebutuhan batu es perusahaan dan juga dijual untuk umum.

Usaha Dagang Lang-lang Buana telah melaksanakan Tanggung Jawab Sosial Perusahaan sesuai dengan doktrin CSR Caroll dimana telah memenuhi

32 Sisi Prisilia dan Epi, Op.Cit., tanggal 10 Maret 2017.

33 Mulyadi, Op.Cit.

34 Hartuti dan Sidan Jauhari Warga Kampung Bali, Hasil wawancara, di Bengkulu, tanggal 4 Maret 2017.

Dora Yulia Agustina, Pelaksanaan Corporate Social Responsibility Oleh perusahaan tidak berbadan hukum.... 
empat lapisan yakni ekonomi, hukum, etika dan sosial. Salah satu upaya Usaha Dagang Lang-lang Buana dalam meningkatkan ekonomi nelayan dengan melakukan pemberian modal berupa alat tangkap ikan. Pemberian alat tangkap ini dilakukan pada tahun 2016. Alat tangkap yang diberikan berupa lancang dan jaring. Nelayan yang mendapatkan alat tangkap ini yakni nelayan di kelurahan Pasar Bengkulu.

Usaha Dagang Lang-lang Buana juga membuka lapangan pekerjaan bagi masyarakat sekitar dengan dibukanya pabrik es maupun perusahaan perikanan ikan tangkap ini. Karyawan yang bekerja di perusahaan ini rata-rata masyarakat di sekitar perusahaan terutama masyarakat disekitar kediaman pemilik perusahaan.

Hukum dimana Usaha Dagang Lang-lang Buana telah melengkapi surat menyurat izin perusahaan berupa Tanda Daftar Perusahaan (TDP), Surat Izin Usaha Perdagangan (SIUP), Surat Izin Tempat Usaha (SITU), Surat Izin Gangguan (HO), dan Surat Izin Usaha Perikanan (SIUP) dan menjaga lingkungan dengan meminimalisir dampak kegiatan usaha terhadap lingkungan.

Usaha Dagang Lang-lang Buana dalam kegiatan usahanya yakni penangkapan ikan menggunakan alat tangkap dan jalur penangkapan ikan yang sesuai dengan Peraturan Menteri Kelautan dan Perikanan Republik Indonesia Nomor 71/PERMEN-KP/2016 tentang Jalur Penangkapan Ikan Di Wilayah Pengelolaan Perikanan Negara Republik Indonesia.

Sesuai dengan Pasal 23 ayat (2) Peraturan Menteri Kelautan dan Perikanan Republik Indonesia Nomor 71/PERMEN-KP/2016 tentang Jalur Penangkapan Ikan Di Wilayah Pengelolaan Perikanan Negara Republik Indonesia, Usaha Dagang Lang-lang Buana menggunakan alat tangkap pukat cincin pelagis besar dengan satu kapal yang dengan ketentuan isi pasal sebagai berikut: API pukat cincin pelagis besar dengan satu kapal sebagaimana dimaksud dalam Pasal 7 ayat (3) huruf $b$ merupakan API yang bersifat aktif, dioperasikan dengan menggunakan ukuran :

a. Mesh size $\geq 2$ inch dan tali ris atas $\leq 700 \mathrm{~m}$, menggunakan APBI berupa rumpon dan lampu dengan total daya $\leq 16.000$ watt, menggunakan kapal motor berukuran > 10 s.d $30 \mathrm{GT}$, dan dioperasikan pada jalur penangkapan ikan II dan Jalur Penangkapan Ikan III di WPPNRI 572, WPPNRI 573, WPPNRI 714, WPPNRI 716, dan WPPNRI 717; dan

b. Mesh size $\geq 2$ inch dan tali ris atas $\leq 1.500 \mathrm{~m}$, menggunakan ABPI berupa rumpon dan lampu dengan total daya $\leq 16.000$ watt, menggunakan kapal motor berukuran > $30 \mathrm{GT}$, dan dioperasikan pada jalur penangkapan ikan III di WPPNRI 572, WPPNRI 573, WPPNRI 714, WPPNRI 716, dan WPPNRI 717.

Usaha Dagang Lang-lang Buana memiliki tujuh kapal cincin yang digunakan untuk penangkapan ikan, rata-rata berukuran 30 sampai dengan 69 GT dengan menggunakan alat tangkap API pukat cincin pelagis besar dengan satu

Dora Yulia Agustina, Pelaksanaan Corporate Social Responsibility Oleh perusahaan tidak berbadan hukum.... 
kapal sesuai dengan ketentuan Pasal 23 ayat (2) huruf b. Wilayah melaut sampai dengan daerah Mentawai, Padang. ${ }^{35}$

Etika dimana Usaha Dagang Lang-lang Buana telah mematuhi hukum ditunjukkan dengan periznan dan melaksanakan kegiatan usaha dengan alat tangkap yang sesuai standar, berinteraksi dengan baik pada masyarakat sekitar dan karyawan dengan melaksanakan kegiatan yang dapat meningkatkan perekonomian masyarakat seperti CSR pada lapisan ekonomi dan salah satu perwujudan menjadi warga korporasi yang baik dengan melaksanakan kegiatan philanthropic. Menjalin hubungan yang baik dengan rekan bisnis dengan mematuhi perjanjian yang telah dibuat.

Philanthropic dimana Usaha Dagang Lang-lang Buana melakukan beberapa kegiatan sosial. Beberapa kegiatan sosial yang telah dilakukan yakni perbaikan masjid, menaikan haji dan umroh secara gratis, pembagian sembako, makan dan doa bersama, pembentukan klub olahraga, dan pogging gratis.

Menaikan haji dan umroh diberikan oleh pemilik perusahaan kepada karyawan, pengurus masjid, jemaat masjid dan masyarakat. Pemberian haji dan umroh ini semuanya diurus oleh pemilik perusahaan dan diberikan uang saku Rp 2.000.000 (dua juta rupiah) untuk penerima haji dan umroh gratis serta Rp 2.000.000 (dua juta rupiah) untuk keluarga yang ditinggalkan selama beribadah. ${ }^{36}$

Pemberian perbaikkan masjid diberikan kepada setiap masjid yang mengajukan proposal pada perusahaan, rata-rata setiap masjid mendapatkan bantuan sebesar Rp 1.000.000 (satu juta rupiah). Dana yang digunakan untuk perbaikkan masjid ini dianggarkan dari 2,5\% hasil kapal. Pemberian dana dilakukan setiap tahun pada saat memasuki Bulan Ramadhan. ${ }^{37}$

Pembagian sembako, makan dan doa bersama dilakukan setiap tahun. Pembagian sembako dilakukan setiap menjelang Bulan Ramadhan sedangkan makan dan doa bersama dilakukan pada bulan-bulan tertentu yang sudah ditentukan. Pada tahun ini makan dan doa bersama dilakukan pada Bulan Februari yang lalu. Penerima sembako, makan dan doa bersama yakni anak yatim, panti asuhan, jompo dan fakir miskin. ${ }^{38}$

Pembentukan Klub Basket Lang-lang Buana bertujuan untuk memberikan wadah untuk remaja yang meminati olahraga ini, dimana pemilik perusahaan telah menyediakan lapangan dan pelatih secara cuma-cuma. Klub basket ini terdiri dari klub basket putra dan putri yang seluruhnya berjumlah 50 orang. 39

Pemberian pogging gratis merupakan kegiatan yang baru pertama kali dilakukan yakni pada tahun 2016 di Kelurahan Kampung Bali. Pogging gratis ini

35 Ibid, tanggal 10 Maret 2017.

36 Saharudin, Badarudin dan Yulines, Hasil wawancara, Bengkulu, tanggal 26 dan 27 Februari 2017.

37 Kamaludin dan Saharudin, Hasil wawancara, Bengkulu, tanggal 27 Februari 2017.

38 Nurbaiti, Amaria, Yara dan Rani, Hasil wawancara, Bengkulu, tanggal 7 dan 11 Maret 2017.

39 Resty Ramadayanti dan Erin Larini, Hasil wawancara, Bengkulu, tanggal 4 Maret 2017.

Dora Yulia Agustina, Pelaksanaan Corporate Social Responsibility Oleh perusahaan tidak berbadan hukum.... 
diberikan dalam rangka meminimalisir penyebaran penyakit yang dibawa oleh nyamuk. ${ }^{40}$

Tanggung jawab sosial perusahaan yang dilakukan Usaha Dagang Langlang Buana telah memenuhi empat lapisan CSR Caroll akan tetapi menurut penulis harus lebih ditingkatkan lagi terutama kegiatan di bidang ekonomi agar dapat mengangkat perekonomian masyarakat sekitar secara merata. Kegiatan dalam bentuk ekonomi yang dilakukan masih sedikit dan tidak berjalan setiap tahun sehingga masih sangat kurang.

\section{PENUTUP}

\section{Simpulan}

Bentuk tanggung jawab sosial perusahaan yang telah dilakukan oleh Usaha Dagang lang-lang Buana di Kota Bengkulu meliputi tiga bentuk. Ketiga bentuk ini sesuai dengan teori tripple bottom line dan konsep pembangunan berkelanjutan yakni ekonomi, sosial dan lingkungan. Bidang ekonomi Usaha Dagang Lang-lang Buana telah membuka lapangan pekerjaan bagi masyarakat dan memberikan bantuan permodalan dalam bentuk alat tangkap. Bidang sosial perusahaan telah melakukan beberapa kegiatan terkait dengan masyarakat sekitar yakni menaikkan haji dan umroh secara gratis, pembagian sembako, perbaikan masjid, makan dan doa bersama, dan pembentukkan klub olahraga basket. Bidang lingkungan Usaha Dagang Lang-lang Buana meminimalisir dampak kegiatan penangkapan ikan dengan menggunakan alat tangkap yang sesuai standar yakni menggunakan pukat cincin (purse seine), kebersihan pantai dan pogging gratis.

Tanggung jawab sosial perusahaan yang dilakukan oleh Usaha Dagang Lang-lang Buana telah sesuai dengan doktrin CSR Carroll, dimana ketiga bentuk tanggung jawab sosial perusahaan yang dilakukan telah meliputi empat lapisan CSR Caroll yakni ekonomi, hukum, etika dan philanthropic.

\section{Saran}

Hal-hal yang perlu diperbaiki dan ditingkatkan dalam kegiatan perusahaan dagang Lang-lang Buana selain tetap melaksanakan tanggung jawab sosial yang telah dilakukan dan terus menambah kegiatan-kegiatan CSR lainnya terutama yang berkaitan dengan kelestarian lingkungan hidup agar kekayaan laut Indonesia dapat terus terjaga. Misalnya dengan melakukan perbaikan terumbu karang, pelepasan benih ikan, dan lain-lain. Usaha Dagang Lang-lang Buana dalam melaksanakan CSR bidang ekonomi hendaknya dilakukan terus menerus setiap tahunnya, dan menambah lagi kegiatan CSR di bidang ekonomi seperti pemberian modal berupa ikan kepada pedagang kecil.

\section{DAFTAR PUSTAKA}

Ambarini, N.S.B. 2010. Corporate Social Responsibility (CSR) Sebagai Instrumen Hukum Ekonomi Di Era Globalisasi. Jurnal Dinamika Hukum, 10(3).

40 Hartuti dan Sidan Jauhari (Warga Kampung Bali), Hasil wawancara), Bengkulu, tanggal 4 Maret 2017.

Dora Yulia Agustina, Pelaksanaan Corporate Social Responsibility Oleh perusahaan tidak berbadan hukum.... 
Supremasi Hukum :Jurnal Penelitian Hukum

p-ISSN: 1693-766X ; e-ISSN: 2579-4663, Vol. 27, No. 1 Januari 2018, 23-37

diunduh

dari

http://www.dinamikahukum.fh.unsoed.ac.id/index.php/JDH/article/view File/101/51. tanggal 25 Maret 2017.

Amaria (Warga Kampung Kelawi),2017, Hasil wawancara, Bengkulu, tanggal 11 Maret.

Badarudin (Karyawan UD.Lang-Lang Buana), 2017. Hasil wawancara, Bengkulu, tanggal 26 Februari.

Burhani, Ruslan. 2007. Kurang dari 50 Persen Perusahaan Laksanakan CSR. dari http://m.antaranews.com/berita/68802/kurang-dari-50-persenperusahaan-laksanakan-csr. diakses tanggal 16 Oktober 2016.

Dinas Kelautan dan Perikanan Provinsi Bengkulu, 2017, Data Perusahaan Provinsi Bengkulu 2017, Bengkulu tanggal 5 Maret.

Larini, Erin (Angota Klub Basket LLB), 2017, Hasil Wawancara), Bengkulu, tanggal 4 Maret.

Hasyim, Farida. 2009. Hukum Dagang. Jakarta: Sinar Grafika.

Hartuti dan Sidan Jauhari (Warga Kampung Bali), 2017. Hasil Wawancara, Bengkulu, tanggal 4 Maret.

Kamaludin; Saharudin (Pengurus Masjid), 2017, Hasil Wawancara, Bengkulu, tanggal 27 Februari.

Mardikanto, Totok.2014. CSR (Corporate Social Responsibility) (Tanggung Jawab Sosial Korporasi), Bandung: ALFABETA.

Muhammad, Abdulkadir. 2004. Hukum dan Penelitian Hukum, Bandung: PT. Citra Aditya Bakti.

Muthiah, Aulia. 2016. Aspek Hukum Dagang dan Pelaksanaannya Di Indonesia. Yogyakarta: PT. Pustaka Baru.

Mulyadi (nelayan). 2017, Hasil Wawancara, Bengkulu 28 Maret.

Nurbaiti (Panti Asuhan Bumi Rafflesia), 2017. Hasil Wawancara, Bengkulu, tanggal 7 Maret.

Prisilia, Sisi dan Epi sulastri (Staf UD. Langlang Buana), 2017, Hasil Wawancara, Bengkulu, 20 Maret.

Dora Yulia Agustina, Pelaksanaan Corporate Social Responsibility Oleh perusahaan tidak berbadan hukum.... 
Supremasi Hukum :Jurnal Penelitian Hukum

p-ISSN: 1693-766X ; e-ISSN: 2579-4663, Vol. 27, No. 1 Januari 2018, 23-37

Rani (Warga Kampung Kelawi), 2017, Hasil Wawancara), Bengkulu, tanggal 11 Maret.

Resty Ramadayanti (Anggota Klub Basket LLB), 2017, Hasil Wawancara), Bengkulu, tanggal 4 Maret.

Sembiring, Sentosa. 2007. Hukum Perseroan Tentang Perseroan Terbatas, Bandung: CV. Nuansa Aulia.

Sumitro, Roni Hanitiyo. 1990. Metodologi Penelitian Hukum dan Jurimetri, Jakarta: Ghalia Indonesia.

Usaha Dagang Lang-lang Buana. 2016. Dokumen Perusahaan, Bengkulu, tanggal 10 November.

Wahyudi, I., \& Azheri, B. 2008. Corporate Social Responsibility : Prinsip, Pengaturan dan Implementasi. Malang: In-Trans Publishing.

Widjaja, G., \& Pratama, Y.A. 2008. Risiko Hukum dan Bisnis Perusahaan Tanpa CSR. Jakarta: Forum Sahabat.

Yara (Warga Kampung Kelawi), 2017. Hasil wawancara, Bengkulu, tanggal 11 Maret.

Yulines (Warga Pasar Bengkulu), 2017, Hasil wawancara, Bengkulu, tanggal 27 Februari.

Dora Yulia Agustina, Pelaksanaan Corporate Social Responsibility Oleh perusahaan tidak berbadan hukum.... 